\title{
CONSTRUCTING ISLAMIC BANKING RESILIENCE INDEX IN INDONESIA
}

\author{
Dimas Bagus Wiranatakusuma ${ }^{1}$
}

\begin{abstract}
Islamic banking plays critical roles in providing essential economic functions and services to the entire financial system and the overall economy. Thus, the bank's strength and resilience is the foundation and pre-condition for achieving sustainable economic growth, given that banks are at the centre of the credit intermediation process between savers and investors. One of the main causes of past financial crisis was that the banking sector had built up excessive both on-and-off balance sheet levereage. To address such financial crisis, the resilience of Islamic banking needs to be developed. Therefore, this paper searches the level of resilience of Islamic banking by building the Islamic Banking Resilience Index (IBRI). The level of resilience is analyzed through the construction of the composite index. The composite is compiled on the basis of several single variables index. Its construction follows an ideal sequence of five steps: theoretical framework, data selection, normalization, weighting and aggregation, and visualization of the result. Twelve variables are used to construct the composite index by using monthly data since January 2010 until December 2016. The composite index is able to figure out the resilience level of Islamic banking in Indonesia over periods of observation. At the resilience level, Islamic banking is able to deal with shocks and stresses, while keep providing financial services. The level of resilience is capable of preserving the elements of banking sector not failing from both crash and stagnation phase. Therefore, construction of IBRI is important as surveillance tools and underlying reason for further policy response and implementation. The composite index, represented by IBRI, is able to show the level of resilience of Islamic banking in Indonesia. The paper finally suggests that the resilience of Islamic banking requires a solid capital and liquidity management in order to provide a stronger ability in absorbing shocks and promoting financial services.
\end{abstract}

Keywords: Islamic Banking, Resilience, Composite Index, Indonesia.

JEL Classification: E44, F15, G01

Received : September 22, 2017

Revised : April 10, 2018

Accepted : May 1, 2018

1. PhD Candidate of Economics in International Islamic University Malaysia and Lecturer at the Economics Department in Universitas Muhammadiyah Yogyakarta. Indonesia, Corresponding author: dimas_kusuma@umy.ac.id. 


\section{INTRODUCTION}

The banks are of paramount importance of the financial system stability and play a pivotal role in the overall economy. Krishnamurti and Lee (2014) suggest that, given such an important role, developing economies need to be seriously concerned with the resilience of the banking system. It is because their financial structure is, typically, a bank-based economy. Furthermore, Crossen et al. (2014) state that banking systems are also exposed to risks and shocks. Moreover, as evidenced by several prior banking crises, risks or shocks that hit one bank may spread to other banks. For example, if a bank is considered "too interconnected to fail", eventually it can jeopardize the stability of entire banking system and even the financial system. Going back to financial crisis events, the main reason for both recent severe financial crises, that is, the 1998 AFC and the 2008 GFC, was that the banking sectors of many countries built up excessive on -and-off balance sheet exposure. This balance sheet overexposure was accompanied by a gradual erosion of both the level and quality of the capital adequacy requirement, as well as holding insufficient capital buffers for liquidity purposes. Therefore, maintaining the resilience of the banking system would reduce the likelihood of a crisis occurring, and automatically preserving the financial system stability.

The resilience of the banking sector can be defined as the capacity of the banking sector to adapt in response to both short-term shocks and long-term economic conditions while continuing to fulfil its functions in serving the real economy. The real economy comprises of nonfinancial companies, households, non-profit organizations, the public sector and non-bank financial institutions. Basically, the ultimate purpose of the banking sector is to serve these sectors and get benefits from the financial intermediary process. Transactions that take place purely between the financial sector and deficit agents should, theoretically and eventually, render some benefits to the real economy. Therefore, the precondition of resilience requires the combination of two essential elements, not only that the banking sector can absorb and adapt to various levels of external shocks, but also maintain its purpose to serve the real economy.

Islamic banking is a component of the financial institutions and global financial system. Even though its size is minuscule compared to conventional banking systems, vulnerability can also exist within it. This is because its operations can be exposed to various financial risks following the credit cycle (Berger and Udell, 2004). For example, the global financial crises slightly increased its nonperforming financing (NPF) ratio since Islamic banking has limited capacity to extend financing, given its limited ability to lend in cash. Furthermore, Hasan and Dridi (2010) argue that a higher NPF reflects the limited exposure of the risk-free government sector and has a relatively higher exposure in the consumer sector. Consequently, the credit cycle behaves procyclically due to the role of excessive financing and losing the quality of financing. The boom-bust mechanism or procyclical behaviour emerges to reflect the credit cycle fluctuation, which is viewed to be a consequence of business cycle and financial cycle fluctuations.

In Indonesia, Islamic banking operates side by side with conventional banking, and enjoys a steady and consistent contribution for boosting economic growth. The development of Islamic banking in Indonesia shows strong growth in terms of assets, deposited funds and financing, roughly $11.73 \%, 13.14 \%$, and 
9.73\%, respectively, in 2014 (Financial Services Authority [Otoritas Jasa Keuangan] [OJK], 2014). Moreover, in the midst of global financial uncertainty and domestic economic turbulence, Islamic banking in Indonesia was able to maintain a strong capital adequacy ratio (CAR) and sound financing-to-deposit ratio (FDR) for around $14.1 \%$ and 96.5\%, respectively, in 2015 (OJK, 2015). Therefore, Islamic banking continues to provide economic functions to the real sector, and is capable of withstanding external adverse shocks.

In addition, Islamic banking contributes positively to the resilience of the global economy. Imam and Kpodar (2010), Eickmeier et al. (2013), and Giudici and Hashem (2015) argue that Islamic banking contributes positively to economic growth and dampens systemic risk in the midst of financial distress. The external shocks that Islamic banking is exposed to be controlled (there is a strong level of resilience), given that Islamic banking is believed to have less idiosyncratic vulnerability. The lower vulnerability is caused by less dependence on leverage, it is risk-sharing based, there is relatively balanced liquidity and it is closely related to the real economy.

Čihák and Hesse (2008) compare the performance of Islamic banking and conventional banking during the recent GFC, and find that on average, Islamic banking showed stronger resilience during the GFC. Čihák and Hesse (2008), Hasan and Dridi (2010) further confirm its strong resilience by observing several facts: it has a lesser degree of exposure to any one sector or borrower, smaller investment portfolios, a higher capital-to-asset ratio, lower leverage and adherence to Shari'ah principles.

However, during the financial crisis, Islamic banking also showed abnormal behavior or a higher vulnerability, which was caused by either banks' balance sheet deterioration or an inability to absorb adverse external shocks. Balance sheet deterioration will probably trigger systemic risk when the transmission channels of external shocks become unpredictable and widen into the entire financial system. Gunadi et al. (2014) identify several channels leading to systemic risk: balance sheets, financial markets, the real sector, infrastructure, and market confidence.

Likewise, Islamic banking, as a financial intermediary, has interlinked relationships through markets and counterparties, which may decrease the occurrence of systemic risk. As a consequence, financial deterioration from various sectors can then easily spill over through those channels and interactions, causing a larger probability of systemic risk in the financial system. As systemic risk becomes problematic, the impacts can be heightened due to the risk-averse behavior of economic agents and the financial institutions squeezing liquidity (Huang et al., 2012).

Based on the above explanation, this study reveals a point of significance regarding study of the resilience of Islamic banking by referring to exogeneous shocks. Exogeneous shocks can propagate and amplify the vulnerability of Islamic banking in the financial system. These shocks are transmitted into the financial system and gradually diminish the resilience of Islamic banking, given that banking vulnerability exists.

In terms of vulnerability issue, Islamic banking faces two types of vulnerabilities: one is related to individual weaknesses (embedded vulnerabilities), such as maturity mismatches; and the other is related to systemic problems or 
external shocks against which an individual bank cannot insure itself (cumulative vulnerabilities), such as credit behavior. Therefore, assessing the vulnerabilities in Islamic banking need backward-looking variables to measure the risk profiling and systemic risk evolution in Islamic banking. Thus, composite indices are then generated, called the Islamic Banking Resilience Index (IBRI), as a proxy to facilitate bank monitoring tasks, particularly determining the level of resilience. In short, this study evaluates the level of resilience of Islamic banking in Indonesia.

The study is structured as follows. Chapter 2 elaborates theoretical framework and literature review. Chapter 3 explores the data and methodology. Chapter 4 discusses findings and sums up in the Chapter 5.

\section{THEORETICAL AND LITERATURE REVIEW}

The resilience of a banking system, including Islamic banking, incorporates the system's ability to withstand external adverse shocks while continuing to provide economic services. To achive such purposes, this chapter explores some theories related to the factors affecting the resilience of a banking system.

\subsection{Theoretical Review}

\subsubsection{Vulnerability Theory}

Mechler et al. (2010) view the concept of vulnerability as the likelihood of experiencing stress due to exogeneous shocks. The degree of vulnerability depends on the geographical location in the context of climate change, including the impact. From an economy point of view, the impact will generate inherent vulnerabilities in the financial system, at which point adaptation and mitigation policies are then required to minimize the impact, and to return the system to its normal position or rate.

\subsubsection{Resilience Theory}

Resilience theory is defined as a system's ability to adapt and reorganize itself as a result of an unanticipated shock. Rose (2009) defines resilience as the amount of disturbance that a system can absorb without changing its state. She further clarifies that resilience has three primary properties, including a reduced probability of failure, which refers to mitigation measures; reduced consequences from failures; and reduced time to recover. These three properties basically explain the role of resilience in dealing with inherent and adaptive capabilities.

\subsubsection{Business Cycle Theory}

Business-cycle theory is useful for explaining fluctuations in some macroeconomic variables. According to Mankiw (2002), one of the three key facts about economic fluctuations is that they are irregular and unpredictable. Fluctuations in the economy are often called the business cycle. This term suggests that economic fluctuations correspond to changes in business conditions. 
Mankiw (2002) states that real GDP is the variable that is most commonly used to monitor short-term changes in the economy because it is the most comprehensive measure of economic activity. When the real GDP grows rapidly, business is good. During economic expansion, firms find that customers are plentiful and that profits are growing. On the other hand, when the real GDP falls during economic recessions, firms have trouble in that, during such periods of economic contraction, most firms experience declining sales and dwindling profits.

\subsubsection{Complex Adaptive System (CAS) Theory}

Laszlo and Krippner (1998) define a system as a complex of interacting components together with the relationships among them that permit the identification of a boundary-maintaining entity or process. Ackoff (1981) suggests that a system is a set of two or more interrelated elements with three properties: (i) each element has an effect on the functioning of the whole; (ii) each element is affected by at least one other element in the system; and (iii) all possible subgroups of elements also have the first two properties. Therefore, a system is basically defined as a group of interacting components that conserves some identifiable set of relations with the sum of the components plus their relations (within the system itself), as well as conserving some identifiable set of relations to other entities (including other systems). In other words, a system is stable or reaching equilibrium if there are organizing forces or relations present that permit the conservation of not only the system's structure, but also its function.

\subsection{Literature Review}

There is no clear cut conclusion on whether Islamic banking is more resilient than conventional banking. Some literature, for example, Farooq and Zaheer (2015), and Abedifar et al. (2013) find that Islamic banking is more resilient due to being better capitalized, having lower loan loss provisioning, having fewer NPLs, having less volatile asset returns, having depositor discipline (Aysan et al., 2015), having a higher intermediation ratio (Beck et al., 2013), having higher average efficiency (Ferhi and Chkoundali, 2015), being less exposed to liquidity risk due to being less sensitive to changes in deposits (Zaheer and Farooq, 2014; Akhtar et al., 2011), and the risks exposed in Islamic banking not being related to efficiency (Ferhi and Chkoundali, 2015).

The main risks in the banking system, including in Islamic banking, are credit and liquidity risks. The credit cycle (Allen and Saunders, 2002), a mismatch of balance sheets (Borio, 2010) and funding constraints (Borio, 2004) are some of triggering factors for risk exposures. These factors could deteriorate the banking system as a result of an inability to diversify their portfolios (Stever, 2007) and loan syndication (Nirei et al., 2014). Therefore, to manage risks in the banking system, credit risk and liquidity risk should be linked with the rate of growth of a bank's aggregate balance sheets by which remains surplus (high liquidity borrowers and short-term debt) (Adrian and Hyun, 2003; Cecchetti et al., 2010; Tirole, 2011; Drehmann and Nikolaou, 2013). 


\subsection{Conceptual Framework}

As illustrated in Figure 1, there are some interactions among various components in the financial system indicating linkages between the resilience of Islamic banking and the stability of financial system. These interactions are essential as basis for building a Resilience of Islamic Banking Index (IBRI) in Indonesia. However, the linkages between them are influenced by a system's ability to withstand external adverse shocks through macroeconomic imbalances. The supervisory authorities then need to establish a mechanism that enables regular assessments on the effectiveness of their supervisory system by conducting risk identification. For example, Mohanty and Turner (2010), and the IFSB (2011) conducted such a risk identification for the cross-sectional risk dimension (institutional determinants of the soundness of the financial system) and time-series risk dimension (macroeconomic environment) for the supervisory process.

In terms of the balance-sheet problem, it is mainly driven by credit and liquidity risk, and deteriorated by procyclical behaviour. Bank Indonesia (2004) states that Islamic banking prefers sales-based financing to equity-based financing; however, sales-based takes a long-term period of financing, but Islamic banking is likely to use short-term funds due to cheaper funds. It creates a problem when a counterparty fails to pay back or suddenly depositors withdraw their funds.

Moreover, if withdrawals occur in a huge volume, then the credit cycle moves up (procycle) and could trap Islamic banking into a severe banking failure. These phenomena may happen frequently in the Islamic banking system. Thus, to improve or at least maintain its resilience, Islamic banking needs to have a framework for crisis prevention and mitigation through several methods, such as signal, logit and stress tests.

Realizing that risks will frequently emerge in banking operations, risk prevention and mitigation policies are needed that maximize the synergies between the micro and macroprudential aspects (Osiński et al., 2013).

The AFC and GFC have renewed policymakers' awareness of the need to make a serious effort to search for a more-effective framework for monitoring the financial sector's vulnerability and fragility. Gadanecz and Jayaram (2009) present the attempts to contribute by using various indicators and the creation of composite indices. Furthermore, Crossen et al. (2014) argue that composite indices can aggregate the attributes of each of the two primary aspects of resilience, financial stability and the provision of economic functions, into a single metric measurement. Thus, developing a resilience index is necessary to monitor the financial stability and summarize the economic functions of the banks. Overall, Figure 1 provides a comprehensive empirical survey on maintaining the stability of a financial system as well as the resilience of banking system, with the following aims: (i) improving its ability to absorb shocks without relying on government support, and (ii) maintaining its ability to perform its essential economic functions, thereby continuing to contribute to the economy's productivity and growth. 


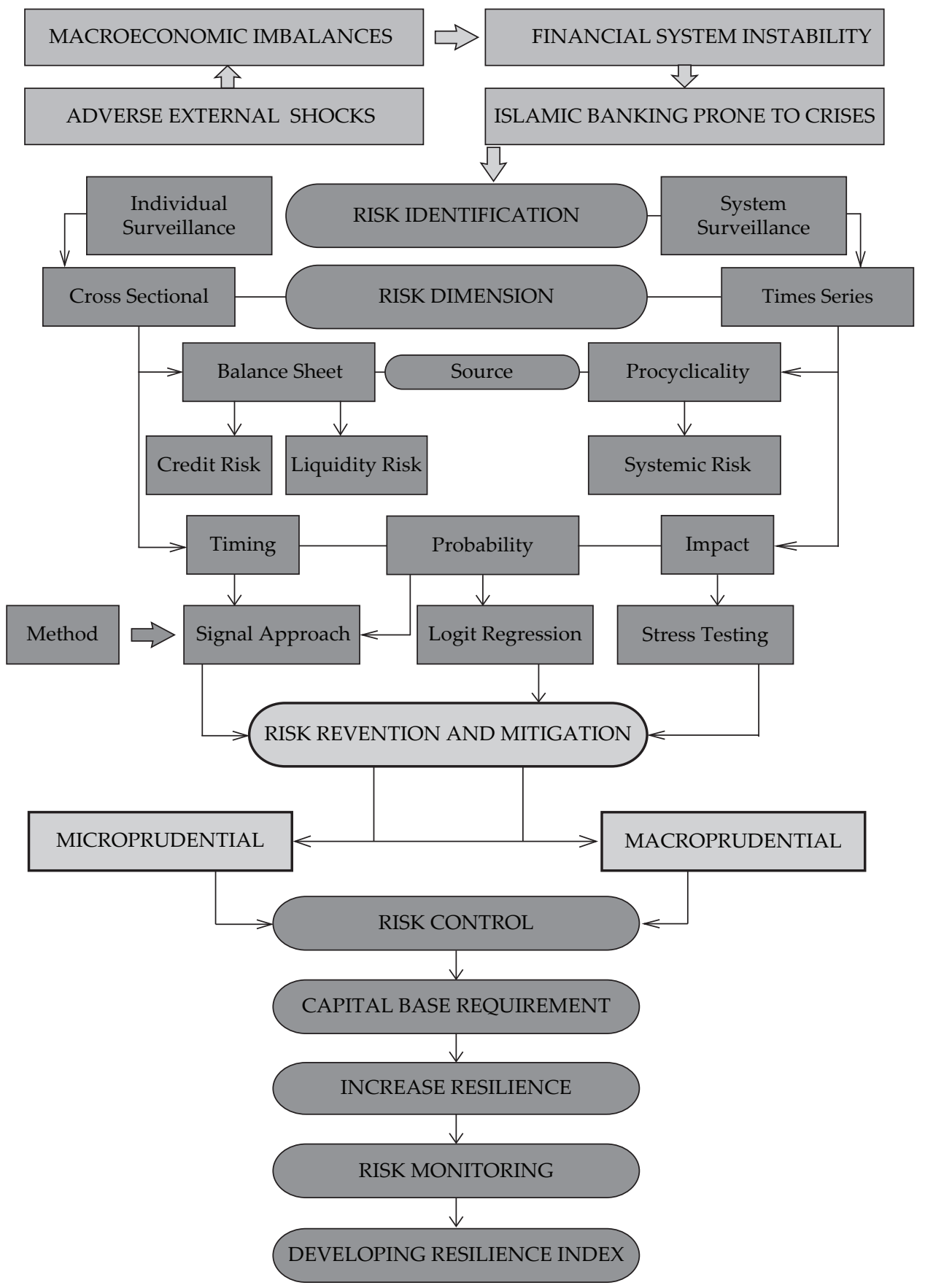

Figure 1.

Framework for Building the Islamic Banking Resilience Index in Indonesia 


\section{DATA AND METHODOLOGY}

This chapter presents an ideal sequence of seven steps, from the development of a theoretical framework to the presentation and dissemination of an Islamic Banking Resilience Index (IBRI) as a composite indicator.

\subsection{Theoretical Framework}

Prior to developing an IBRI as a composite index, variable, individual indicator, dimension objectives and composite indicator are defined.

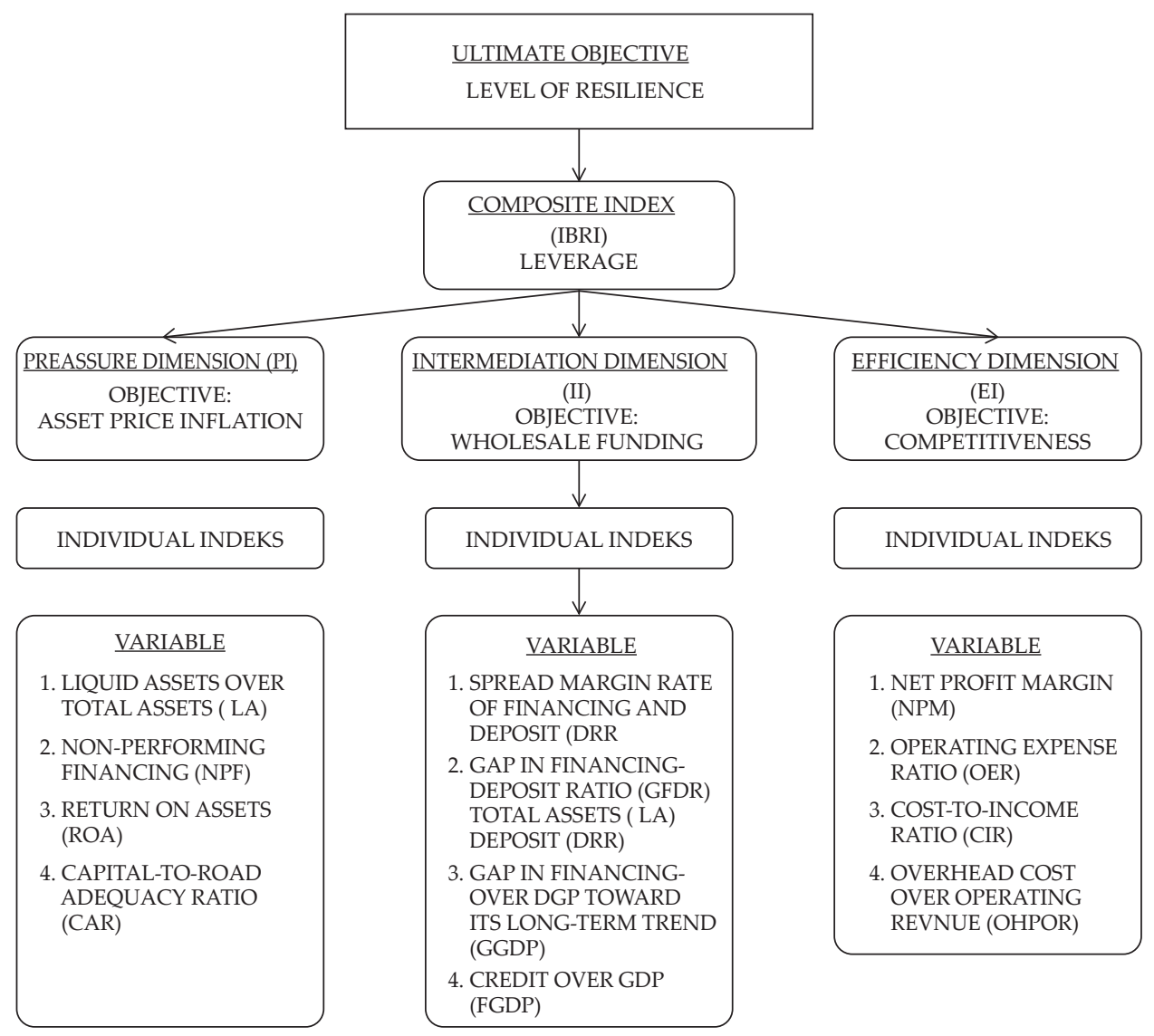

Figure 2.

The Hierarchical Level of Building a Composite Index

Figure 2 shows the level of hierarchy needed to construct the composite index. The ultimate objective of the index is to use it as a tool to test for the level of resilience of Islamic banking in Indonesia. The resilience is reflected through the capacity of the index, called the IBRI, to measure the level of resilience of Islamic banking in Indonesia. As described by Briguglio et al. (2008), resilience basically 
covers two distinct elements: first, the ability of an economy to recover quickly following adverse shocks (shock counteraction) and, second, the ability of an economy to withstand shocks (shock absorption). Therefore, to achieve such a level of resilience, a clear sense of what is being measured by the composite index should be defined.

\subsubsection{Diversity and Competitiveness (Efficiency Dimension)}

Banks' diversity and competitiveness relate to the efficiency aspect of a bank. As noted by Haldane and May (2011), the degree of diversity will determine the level of competitiveness of a bank. A less diversified or homogeneous banking sector indicates that all banks are doing the same thing at the same time, which can minimize the risk for each individual bank. Less diversification in the banking sector represents banking competitiveness where it encourages banks to then adopt a lower, and even uniform, capital and liquidity level. In the midst of higher competitiveness, banks face a higher level of efficiency, but a lower level of resilience. In contrast, a more diversified banking sector can turn its elements into shock absorbers rather than transmitters.

\subsubsection{Asset Composition (Pressure Dimension)}

Islamic banks practically extend financing through two main, distinct allocations: the allocation of credit to the financial or asset market (non-GDP), and allocation to the real sector (GDP). The resilience of Islamic banking can mainly be destroyed due to the excessive allocation of financing to non-GDP transactions. Financing to non-GDP transactions drives credit-cycle fluctuations, indicating Islamic banking is taking risk. The risk-taking could trigger imbalances among the economic sectors because a gap emerges between the supply of financing and the economic capacity. Once the gap becomes wider, the economy overheats and this results in economic growth, but it does not represent the economic fundamental.

Deviating from the fundamental causes economic bubbles, stemming from the gap between financing and economic capacity. The existence of a gap will trigger the raising of the asset price; for example, in residential assets. Asset inflation is reflected by the phenomena of house-price bubbles in Indonesia. According to Bank Indonesia, property prices have increased by around $44 \%$ between 2007 and 2014 in the five biggest cities in Indonesia, and its growth exceeds the income growth.

\subsubsection{Liability Composition (Intermediation Dimension)}

A bank, as a financial intermediary, has the ability to create leverage and engage in maturity transformation. This intermediary function affects the resilience of the banking sector through banks' balance sheets when solvency and liquidity risks materialize. Liability composition determines the resilience as liabilities are structured by volatile funds. In recent decades, there has been a shift in funding composition where banks increase their reliance in borrowing across financial institutions (wholesale funding), often on a very-short-term basis. In fact, the type 
of bank funding is a key point in assessing banks' ability to withstand various adverse shocks, particularly those related to short-term wholesale funding. Hahm et al. (2012) argue that high reliance in wholesale funding can increase vulnerability in the banking sector since this funding is volatile and behaves procyclically, where it expands rapidly during booms and suddenly collapses following a crisis.

\subsection{Data Selection}

The selection of basic data should maximize the overall quality of the final IBRI as a composite indicator. As shown on Figure 3.1, the IBRI is constructed from twelve variables, which represents three dimensions, including pressure, intermediation, and efficiency. In terms of the data, all variables are retrieved from Islamic Banking Statistics, Bank Indonesia, from January 2012 to December 2016 on monthly basis as the period of observation.

Table 1.

The Underlying Reasons for Selecting the Year of Observation

\begin{tabular}{clcr}
\hline No & \multicolumn{1}{c}{ Item } & Rationale & \multicolumn{1}{c}{ Output } \\
\hline 1 & Period of Leveraging & Addresses Financial Cycle & $\begin{array}{r}\text { Lowest Standard Deviation } \\
\text { (Base Year) }\end{array}$ \\
2 & $\begin{array}{l}\text { Financial Services Authority } \\
\text { Act Year 2011 }\end{array}$ & Macroprudential Policy & $\begin{array}{r}\text { Minimized Systemic Risk } \\
3\end{array}$ \\
Islamic Banking Act 2008 & Microprudential Policy & Stronger Resilience \\
\hline Overall, the year 2012 is a period of a new normal for measuring the level of resilience of Islamic banking in Indonesia
\end{tabular}

\subsection{Normalization}

A composite index is a way of summarizing complex phenomena; however, most of the time the individual variables forming the composites have different measurement units. Therefore, it is necessary to bring these variables into the same unit of measure to avoid figuratively trying to add up pears and apples.

For each individual variable $X_{i}^{t}$, the average individual variable $\bar{X}_{\bar{i}}^{t}$ and the standard deviation $\sigma_{i}^{t}$ are calculated. The normalization formula is as follows:

$$
I_{i}^{t}=\frac{X_{i}^{t}-\overleftarrow{X}_{\bar{i}}^{t}}{\sigma_{i}^{t}}
$$

\subsection{Weighting and Aggregation}

Central to the construction of a composite index is the need to combine different dimensions measured on different scales in a meaningful way. This implies a decision will be made on which weighting model will be used and which procedure will be applied to aggregate the information. Weighting implies a subjective evaluation, which is particularly delicate in the case of complex, interrelated and multidimensional phenomena. This study adopts unequal weighting - all normalized variables are not given the same weight. 


\subsection{Visualization of Islamic Banking Resilience Index (IBRI)}

The IBRI must be able to communicate a story to decision-makers and other end users quickly and accurately. As mentioned in the initial section, the overall steps for construction of a composite index are used to develop the IBRI for Indonesia. The IBRI serves three distinct purposes: (i) providing a clear understanding and definition of the multi-dimensional phenomenon to be measured, including the variables within the pressure, intermediation and efficiency dimensions; (ii) providing a nested structure for the various dimensions of the phenomenon, based on diversity and interconnectivity, and asset and liability composition; and (iii) identifying the selection criteria for the underlying dimensions, including discovering the optimal level that will allow Islamic banking to continue to provide its economic functions, while having the ability to absorb external.

\section{RESULT AND DISCUSSION}

During both the AFC and GFC, the capital requirement in the banking sector was eroded due to its excessive on- and off-balance-sheet leverage. The build-up of leverage in the banking sector amplified the downward pressure on asset prices, exacerbating the positive feedback loop between financial losses, declining bank capital and the contraction of the credit supply.

Basically, resilience is measured by the leverage ratio, which affects the resilience of Islamic banking. The resilience, proxied by the leverage ratio, depends on the dynamic changes in the capital and liquidity aspects. Their dynamics are basically determined by banks' diversity and competitiveness, assets, and liabilities' composition.

\subsection{Developing a Theoretical Framework}

The resilience of the banking sector is often linked to financial cycles. Typically, a simultaneous boom in asset prices and lending, followed by a sharp decline, can be observed prior to a crisis. Historical evidence tends to confirm that there is a close link between asset-price cycles and banking-sector problems. Rising prices for assets during boom markets could have a twofold effect on lending, namely leveraging and deleveraging. During the leveraging phase, rising asset prices tend to stimulate economic activity, triggering the need for increasing private-sector financing. In addition, higher prices raise the value of collateral, thereby reducing the cost of borrowing. As a result, lending will be stimulated, which causes a further rise in asset prices.

Moreover, banks tend to underestimate credit risks when prices are rising and the economic environment is flourishing. In the midst of fierce competition, creditrisk premiums are squeezed and more risky projects receive financing. However, during the deleveraging phase, self-enforcing interactions between lending and asset prices are more pronounced. In this phase, many borrowers cannot fulfil their debt obligations and therefore are forced to sell their assets, so prices gradually decline. Collateral value diminishes, credit costs rise and the supply of financing is limited. These conditions could lead to systemic banking problems since credit is no longer available or constrained to financing the purchase of assets; this 
Table 2. The Summary of the Contributions of the Dimensions and Variables to the Resilience of Islamic Banking

\begin{tabular}{clcc}
\hline & \multicolumn{1}{c}{ Characteristic of Variables } \\
\cline { 2 - 4 } No & $\begin{array}{c}\text { Crash } \\
\text { (Too Excessive - } \\
\text { Shock } \\
\text { Transmitter) }\end{array}$ & $\begin{array}{c}\text { Stagnation } \\
\text { (Too Prudent }- \\
\text { Shock Absorber) }\end{array}$ & $\begin{array}{c}\text { Resilience (Optimal - Shock Absorber and } \\
\text { Prudent Banking Services) }\end{array}$ \\
\hline \multicolumn{2}{c}{} & \multicolumn{2}{c}{ Pressure Dimension } \\
\hline 1 & Higher NPF & Lower NPF & Lower NPF $<$ Balance $<$ Higher NPF \\
2 & Lower CAR & Higher CAR & Lower CAR $<$ Balance $<$ Higher CAR \\
3 & Lower ROA & Higher ROA & Lower ROA $<$ Balance $<$ Higher ROA \\
4 & Lower Liquid Assets & Higher Liquid Assets & Lower Liquid Assets $<$ Balance $<$ Higher Liquid Assets \\
\hline & & \multicolumn{2}{c}{ Intermediation Dimension } \\
\hline 1 & Lower DRR & Higher DRR & Lower DRR $<$ Balance $<$ Higher DRR \\
2 & Higher GGDP & Lower GGDP & Lower GGDP $<$ Balance $<$ Higher GGDP \\
3 & Higher GFDR & Lower GFDR & Lower GFDR $<$ Balance $<$ Higher GFDR \\
4 & Higher FGDP & Lower FGDP & Lower FGDP $<$ Balance $<$ Higher FGDP \\
\hline & & \multicolumn{2}{c}{ Efficiency Dimension } \\
\hline 1 & Higher NPM & Lower NPM & Lower NPM $<$ Balance $<$ Higher NPM \\
2 & Higher OER & Lower OER & Lower OER $<$ Balance $<$ Higher OER \\
3 & Higher CIR & Lower CIR & Lower CIR $<$ Balance $<$ Higher CIR \\
4 & Higher OHPOR & Lower OHPOR & Lower OHPOR $<$ Balance $<$ Higher OHPOR \\
\hline
\end{tabular}

eventually leads to falling asset prices, reduced collateral value and defaulting borrowers reinforcing each other, forcing banks to realize more losses.

\subsection{Data Selection}

The quality of the basic data can be measured only through estimating the optimal threshold of the composite index. A composite index is used as it aggregates and represents all selected variables in the study. In this regard, the optimal threshold is based on four criteria: (i) the minimum loss function; (ii) the lowest QPS (quadratic probability score), (iii) the lowest GSB (global score bias) and (iv) the optimal signal horizon. 
Table 3.

Estimating the Optimal Thresholds with Some Measurement Criteria

\begin{tabular}{llrrr}
\hline \multirow{2}{*}{ Item } & \multirow{2}{*}{ Signalling Horizon } & \multicolumn{3}{c}{ Upper Threshold Evaluations } \\
\cline { 3 - 5 } & & $\mathbf{m}=\mathbf{1 . 3}$ & $\mathbf{m}=\mathbf{1 . 7}$ & $\mathbf{m}=\mathbf{2 . 0}$ \\
\hline \multirow{3}{*}{ Loss Function } & 24 Months & 0.283 & 0.250 & 0.200 \\
& 12 Months & 0.200 & 0.208 & 0.208 \\
QPS & 6 Months & 0.100 & 0.108 & 0.117 \\
GSB & 3 Months & 0.050 & 0.058 & 0.058 \\
& 24, 12, 6 and 3 Months & $93.33 \%$ & $91.67 \%$ & $91.67 \%$ \\
Loss Function & 24, 12,6 and 3 Months & $100 \%$ & $99.97 \%$ & $99.97 \%$ \\
& 24 Months & 0.425 & 0.458 & 0.442 \\
QPS & 12 Months & 0.208 & 0.242 & 0.250 \\
GSB & 6 Months & 0.083 & 0.100 & 0.083 \\
\hline
\end{tabular}

Note: Both QPS and GSB are in fact in the form of values between 0 and 2. However, for easier understanding, the study converts these values into percentages, where a value closer to $100 \%$ indicates the real value is closer to 0 , and a value closer to $0 \%$ is closer to a real value of 2 .

As revealed in Table 3, the optimal threshold is determined by using a multiplier (m) equal to 1.3, applicable to both upper and lower thresholds. These thresholds are selected by considering (i) various signalling horizons, (ii) the lowest loss function, (iii) the highest percentage of QPS or the lowest value of QPS, and (iv) the highest percentage of GSB or lowest value of GSB. The thresholds determined imply that it is suggested that all variables use the 3-month signal horizon, and the thresholds are obtained by using a multiplier (m) equal to 1.3.

\subsection{Normalization}

The standardization method is the most commonly used because it converts all variables to a common scale with an average of 0 and standard deviation of 1 . The average of 0 means that the standardization avoids introducing aggregation distortions stemming from differences in the variables' means.

Table 4.

The Standardization Method for Indexing Variables

\begin{tabular}{|c|c|c|}
\hline \multicolumn{3}{|c|}{ Standardization Method with Base Year 2011 for Indexation (I) } \\
\hline Aggregated Index & Dimensional Index & Individual Indices \\
\hline Composite Index & Pressure Index & INPF, IROA, ICAR and ILA \\
\hline (IBRI) & Intermediation Index & IDRR, IGFDR, IFGDP and IGGDP \\
\hline & Efficiency Index & INPM, ICIR, IOER and IOHPOR \\
\hline
\end{tabular}


Table 4 shows that each individual variable is transformed into an individual index according to its dimension using the standardization method. The year 2011 is used as the reference year or base year, which can then be used to measure the level of deviation and extreme values of overall variables' index. Thus, the output of the standardized variables is used to aggregate and construct the dimensional index and the composite index.

\subsection{Weighting and Aggregation}

This study adopts linear aggregation, since all variables have the same measurement unit and further ambiguities related to the scale effects have been neutralized. Furthermore, linear aggregation implies full and constant compensability - poor performance in some variables can be compensated for by the sufficiently high values for other variables. Therefore, in linear aggregation, there is no conflict effect among the variables and it rewards variables proportionally to their weights. In this study, the linear aggregations for constructing the IBRI are as follows:

$$
I B R I_{t}=\left(w_{p} * I_{t p}\right)+\left(w_{i} * I_{t i}\right)+\left(w_{e} * I_{t e}\right)
$$

Where $I B R I_{t}$ is an aggregated composite index at time $t ; w_{p^{\prime}} w_{i}$ and $w_{e}$ are the weights of the pressure dimension $(p)$, intermediation dimension $(i)$ and efficiency dimension (e), respectively; and $I_{t p^{\prime}} I_{t i}$ and $I_{t e}$ are the values of the dimensional index (pressure, intermediation, and efficiency) at time $t$.

Table 5.

The Indexation and Aggregation Results

\begin{tabular}{llcccccc}
\hline \multirow{2}{*}{ Measurement Unit } & \multicolumn{6}{c}{ Average Value } & Threshold \\
\cline { 2 - 6 } & $\mathbf{2 0 1 2}$ & $\mathbf{2 0 1 3}$ & $\mathbf{2 0 1 4}$ & $\mathbf{2 0 1 5}$ & $\mathbf{2 0 1 6}$ & Level \\
\hline 1 & IBRI & 2.19 & 1.73 & 1.85 & -0.94 & -1.75 & $-0.27-1.27$ \\
2 & PI (Pressure Index) & 2.13 & 0.26 & 0 & 0 & 0 & $-0.42-1.39$ \\
3 & II (Intermediation Index & 2.02 & -3.94 & -1.64 & 0.55 & -0.95 & $1.85-2.41$ \\
4 & EI (Efficiency Index) & 2.23 & -5.09 & -1.46 & 1.96 & -1.26 & $-0.64-1.16$ \\
5 & INPF & 3.7 & 5.93 & 1.59 & -7.41 & -0.52 & $-1.3-1.3$ \\
6 & IROA & 4.41 & 1.5 & 3.84 & -7.94 & -1.18 & $-1.3-1.3$ \\
7 & ICAR & 2.19 & 1.73 & 1.85 & -0.94 & -1.75 & $-1.3-1.3$ \\
8 & ILA & 2.13 & 0.26 & 0 & 0 & 0 & $-1.3-1.3$ \\
9 & IDRR & 2.02 & -3.94 & -1.64 & 0.55 & -0.95 & $-1.3-1.3$ \\
10 & IGFDR & 2.23 & -5.09 & -1.46 & 1.96 & -1.26 & $-1.3-1.3$ \\
11 & IFGDP & 3.7 & 5.93 & 1.59 & -7.41 & -0.52 & $-1.3-1.3$ \\
12 & IGGDP & 4.41 & 1.5 & 3.84 & -7.94 & -1.18 & $-1.3-1.3$ \\
13 & INPM & 2.19 & 1.73 & 1.85 & -0.94 & -1.75 & $-1.3-1.3$ \\
14 & ICIR & 2.13 & 0.26 & 0 & 0 & 0 & $-1.3-1.3$ \\
15 & IOER & 2.02 & -3.94 & -1.64 & 0.55 & -0.95 & $-1.3-1.3$ \\
16 & IOHPOR & 2.23 & -5.09 & -1.46 & 1.96 & -1.26 & $-1.3-1.3$ \\
\hline Resilience $\left(\sum\right.$ Unit) & 1 & 3 & 3 & 7 & 11 & 5 \\
Fragile $\left(\sum\right.$ Unit) & 15 & 13 & 13 & 9 & 5 & 11 \\
Total $\left(\sum\right.$ Unit) & 16 & $\mathbf{1 6}$ & $\mathbf{1 6}$ & $\mathbf{1 6}$ & $\mathbf{1 6}$ & Average \\
\hline
\end{tabular}

Note: For resilience, the green colour shows the value is within the resilience threshold 
Table 5 shows the indexation results stemming from the normalized variables and the weighting aggregation method. The colours are used to distinguish between the resilience and fragile conditions. The conditions are obtained after being compared with their respective levels of threshold. In general, the number of units showing the resilience values is fewer than measurement units showing the fragility values. In addition, in terms of the dimensional contribution towards the resilience of Islamic banking, the pressure dimension contributes much towards its resilience, but the efficiency dimension shares the least contribution towards its resilience.

\subsection{Visualization of Islamic Banking Resilience Index (IBRI)}

Figure 3 shows some aspects of the resilience of Islamic banking. The first aspect is related to the optimum level of resilience, which indicates the range in which system sustainability is well preserved. This preservation is due to the fact that, at an optimal level, the highest level of resilience is achieved, which is reflected by Islamic banking's ability to absorb shocks while still providing economic services.

The second aspect, referred to as the left-hand side, and is where Islamic banking is prone to a crash. In this range, Islamic banking can act as a shock transmitter because its operations are characterized by higher lending, less capital, less liquidity, higher competition and less diversified lending allocation. These conditions make the banking system unsustainable, prone to systemic banking problems and ultimately reduces the resilience of Islamic banking.

The third aspect, referred to as the right-hand side, has the opposite conditions to the second aspect. This aspect reflects some conditions where Islamic banking tends to stagnate as it becomes too prudent with respect to resisting shocks and neglects its economic services. The stagnation is characterized by lower lending, higher capital and liquidity adequacy, lower competition, and a highly diversified lending allocation.

\section{Sustainability}

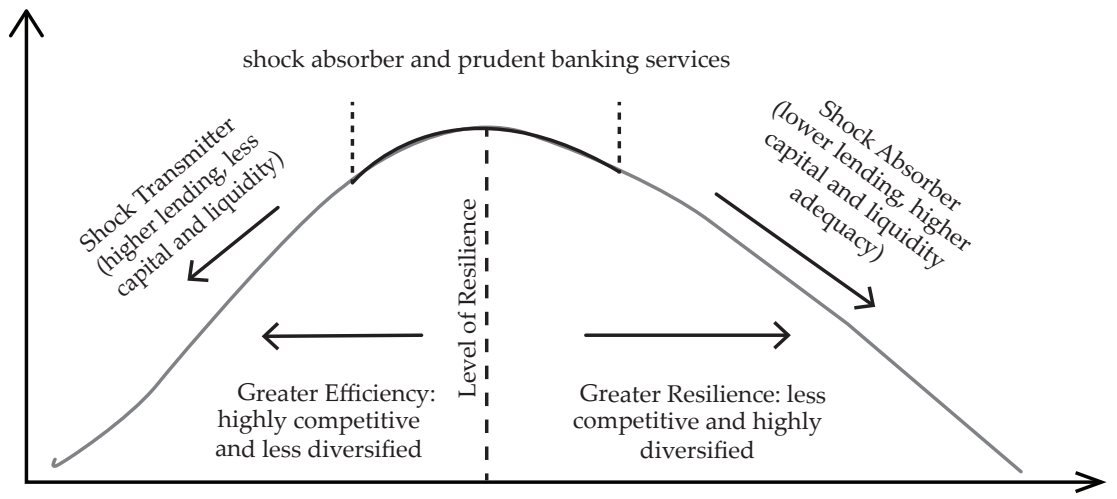

Diversity and Interconnectivity

Figure 3.

The Optimum Level for the Resilience of Islamic Banking 
As a result of these three aspects, this section focuses on conveying the role of the IBRI as a composite index for establishing and maintaining the level of resilience of Islamic banking. The level of resilience reflects the condition where Islamic banking is able to deal with shocks and stresses, while continuing to function well in terms of its financial services (sharing benefits with its environment).

The level of resilience is established and maintained when the optimal thresholds are set under certain conditions, which are formulated as follows:

Threshold level of resilience:

$$
(\overleftarrow{X}-(1.3 * S))<X_{t}<(\overleftarrow{X}+(1.3 * S))
$$

\section{CONCLUSION}

The level of resilience, which is shown by the IBRI is important for several reasons, including the following:

(i) It reflects a condition where Islamic banking is able to deal with shocks, while continuing to share benefits with its environment;

(ii) It provides confidence in the system, as the system can impede its elements from failing into a crash and stagnation phase;

(iii) It provides a range in which Islamic banking can recover quickly after adverse shocks (shock counteraction) and withstand shocks (shock absorption); and

(iv) It reflects the ability of Islamic banking to return to its single, multiple or adapted state following a shock.

From a policymakers' point of view, the level of resilience is the ability to manage banking activities, including facilitating the efficient creation and allocation of financing, promoting the balanced intermediation of financial capital and risk, and strengthening its level of efficiency. The failure to fulfil those conditions will create pressure on capital, a liquidity shortage, and highly concentrated or less diversified banks' financing.

\section{REFERENCES}

Abedifar, P., Molyneux, P., and Tarazi, A. (2013). Risk in Islamic Banking. Review of Finance, 17(6), 1-62. http://doi.org/10.1093/rof/rfs041

Ackoff, R. L. (1981). The Art and Science of Mess Management. Pennsylvania. Retrieved from http://pubsonline.informs.org/doi/abs/10.1287/inte.11.1.20

Adrian, T., and Hyun Song Shin. (2003). Liquidity and Financial Cycles (No. 256). BIS Working Papers. Basel. Retrieved from http://www.bis.org/publ/work256.pdf

Allen, L., and Saunders, A. (2002). A Survey of Cyclical Effects in Credit Risk Measurement Models (No. 126). BIS Working Papers. Basel. Retrieved from http:// www.bis.org/publ/work126.pdf

Aysan, A. F., Disli, M., Ozturk, H., and Turhan, I. M. (2015). Are Islamic Banks Subject To Depositor Discipline? (No. 871). Working Paper. Ghent. Retrieved from http:// www.worldscientific.com/doi/10.1142/S021759081550001 
Beck, T., Demirguc-Kunt, A., and Merrouche, Q. (2013). Islamic vs. Conventional banking: Business Model, Efficiency and Stability. Journal of Banking and Finance, 37(2), 433-447. http://doi.org/10.1016/j.jbankfin.2012.09.016

Berger, A. N., and Udell, G. F. (2004). The Institutional Memory Hypothesis and the Procyclicality of Bank Lending Behaviour (No. 125). BIS Working Papers. Basel. Retrieved from http://www.bis.org/publ/work125.pdf

Borio, C. (2010). Ten Propositions about Liquidity Crises (No. 293). BIS Working Papers. Basel. Retrieved from http://www.bis.org/publ/work293.pdf

Borio, C. (2004). Market Distress and Vanishing Liquidity: Anatomy and Policy Options (No. 158). BIS Working Papers. Basel. Retrieved from http://www.bis.org/publ/ work158.pdf

Cecchetti, S. G., Fender, I., and Patrick McGuire. (2010). Toward a Global Risk Map (No. 309). BIS Working Papers. Basel. Retrieved from http://www.bis.org/publ/ work309.pdf

Čihák, M., and Hesse, H. (2008). Islamic Banks and Financial Stability: An Empirical Analysis. IMF Working Paper (Vol. 08). Washington DC. Retrieved from http:// www.imf.org/external/pubs/ft/wp/2008/wp0816.pdf

Drehmann, M., and Nikolaou, K. (2013). Funding Liquidity Risk: Definition and Measurement (No. 316). BIS Working Papers. Basel. Retrieved from http://www. bis.org/publ/work316.pdf

Eickmeier, S., Gambacorta, L., and Hofmann, B. (2013). Understanding Global Liquidity (No. 402). BIS Working Papers. Basel. Retrieved from http://www.bis. org/publ/work402.pdf

Ferhi, A., and Chkoundali, R. (2015). Credit Risk and Efficiency : Comparative Study between Islamic and Conventional Banks during the Current Crises. Journal of Research in Economics and International Finance, 3(1), 47-56.http://doi. org/10.12691/jbe-3-1-6

Hasan, M., \& Dridi, J. (2010). The Effects of the Global Crisis on Islamic and Conventional Banks: A Comparative Study (10 No. 201). Washington DC. Retrieved from https://www.imf.org/en/Publications/WP/Issues/2016/12/31/The-Effectsof-the-Global-Crisison-Islamic-and-Conventional-Banks-A-ComparativeStudy-24183

Imam, P., and Kpodar, K. (2010). Islamic Banking: How Has it Diffused? IMF Working Paper (Vol. 10). Washington DC. Retrieved from https://www.imf.org/external/ pubs/ft/wp/2010/wp10195.pdf

Giudici, P., and Hashem, S. (2015). Systemic risk of Islamic Banks (No. 103). DEM Working Paper Series. Pavia. Retrieved from http://economia.unipv.it/docs/ dipeco/quad/ps/RePEc/pav/demwpp/DEMWP0103.pdf

Gunadi, I., Elis, D., Advis, B., Kusumawijaya, Iqbal Hadyan Purnama, D., and Almuldita, N. N. (2012). Pengembangan Bank Indonesia Indeks Stabilitas Keuangan (BISK). Bank Indonesia Working Paper. Jakarta.

Huang, X., Zhou, H., and Zhu, H. (2012). Assessing the Systemic Risk of a Heterogeneous Portfolio of Banks during the Recent Financial Crisis (No. 296). BIS Working Papers. Basel. Retrieved from http://www.bis.org/publ/work296.pdf

Krishnamurti, D., and Lee, Y. C. (2014). Macroprudential Policy Framework: A Practice Guide (1st ed.). Washington DC: World Bank. Retrieved from http://www-wds. worldbank.org/external/default 
Mohanty, M. S., and Turner, P. (2010). Banks and Financial Intermediation in Emerging Asia: Reforms and New Risks (No. 313). BIS Working Paper. Jakarta. Retrieved from http://www.bis.org/publ/work313.pdf

Nirei, M., Caballero, J. A., and Sushko, V. (2014). Bank Capital Shock Propagation Via Syndicated Interconnectedness (No. 484). BIS Working Papers. Basel. Retrieved from http://www.bis.org/publ/work484.pdf

Laszlo, A., \& Krippner, S. (1998). Systems Theories: Their Origins, Foundations, and Development. (Elsevier, Ed.) (J.S. Jorda). Amsterdam.

Osiński, J., Seal, K., and Hoogduin, L. (2013). Macroprudential and Microprudential Policies: Toward Cohabitation. IMF Staff Discussion Note (Vol. 13). Washington DC. Retrieved from https://www.imf.org/external/pubs/ft/sdn/2013/sdn1305. pdf

Otoritas Jasa Keuangan. (2014). Islamic Banking Statistics. Monthly Report. Jakarta. Retrieved from http://www.bi.go.id/id/statistik/perbankan/syariah/ Documents/SPS Desember 2014.pdf

Rose, A. K., \& Spiegel, M. M. (2009). Cross-Country Causes and Consequences and American Exposure International Linkages and American Exposure (No. 18). San Franscisco. Retrieved from http://www.frbsf.org/economic-research/files/ wp09-18bk.pdfhttps://www.academia.edu/713345/Systems_Theories_Their_ origins_foundations_and_development?auto=download

Stever, R. (2007). Bank Size, Credit and the Sources of Bank Market Risk (No. 238). BIS Working Papers. Basel. Retrieved from http://www.bis.org/publ/work238.pdf

Tirole, J. (2011). Illiquidity and All Its Friends (No. 303). BIS Working Papers. Basel. Retrieved from http://www.bis.org/publ/work303.pdf

Zaheer, S., and Farooq, M. (2014). Liquidity Crisis : Are Islamic Banking Institutions More Resilient? IMF Working Paper. Washington DC. Retrieved from https:// www.imf.org/external/np/seminars/eng/2014/lic/pdf/Farooq.pdf. 